\title{
How a farming environment protects from atopy
}

Julie Deckers ${ }^{1}$, Bart N Lambrecht $1,2,3$ and Hamida Hammad ${ }^{1,2}$

1. Laboratory of Immunoregulation and Mucosal Immunology, VIB Center for Inflammation Research, Technologiepark 927, B-9052 Ghent (Zwijnaarde), Belgium 2. Department of Internal Medicine and Pediatrics, University Hospital Ghent, De Pintelaan 185 K12, B-9000 Ghent, Belgium

3. Department of Respiratory Medicine, Erasmus Medical Center, Rotterdam, The Netherlands

\section{Corresponding author:}

Bart N Lambrecht

Technologiepark-Zwijnaarde 71

9052 Zwijnaarde, Belgium

Tel: +3293313740

email: bart.lambrecht@ugent.be

\section{Highlights:}

- Growing up in farms protect from developing allergies later in life

- Farm-induced protection is mediated by a gene-environment interaction

- Farm dust components confer protection by acting on both barrier and immune cells 


\begin{abstract}
It is now well established that the exposure to certain environments like farms have the potential to protect from the development of allergies later in life. This protection is achieved when repeated exposure to the farming environment occurs early in life, but persists when children spend sufficient amount of time in contact with livestock and hay, and drink unpasteurized milk. The capacity of farm dust to protect from allergy development lies mainly in the microbe composition in the farm. These protective microbes can produce metabolites and colonize various barrier sites (skin, lung, intestine) in children, leading to persistent changes in the way their immune system and their barrier cells respond to environmental allergens.
\end{abstract}

\title{
Introduction
}

The prevalence of allergic diseases like allergic rhinitis, asthma and atopic dermatitis is on a steep rise since World War II [1]. Currently, more than $30 \%$ of children in Westernized countries have allergies $[2,3]$. The fact that this remarkable increase in the prevalence of allergies occurred within such a short time implies environmental influences above genetics. The Western lifestyle is associated with reduced environmental biodiversity and an altered host microbiome and we know now that this implies a lack of instructive signals for the developing immune system [4]. Therefore, exploring what environmental cues regulate human immune responses and unraveling mechanistic pathways is of major interest to develop prevention therapies that can halt the rise of allergic diseases. This review will summarize what has been explored until now and some recent advances to mechanistically explain how a farming environment protects against allergies.

\section{Farming and atopy}

The protective effect of a farming environment on transient wheeze and atopy is now generally established by multiple epidemiological studies [5]. Altogether, they revealed that several farm-related factors could contribute to protection from atopy (Figure 1).

For instance, contact with livestock, particularly cows [6], has long been identified as a major contributing factor to protect from rhinitis, asthma and atopy $[7,8]$. The protective farm effect is stronger in children of full-time farmers compared to children of part-time farmers [8], and residential proximity to livestock can protect non-farmers' children from atopy but to a lesser extent than farmer's children [9]. This indicates that contact with livestock protects in a dose-responsive way. In fact, Amish farm children, who live in very close proximity to livestock, are even better protected from atopy than the European farm children [10]. This was not the case for Hutterite farm children, sharing genetic background with Amish children but live more distant from highly industrialized farms [10]. Early exposure to a farming environment appears to be crucial for the protective effect [11]. Actually, a life-long exposure to a farming environment is optimal to confer protection from atopy from childhood until adulthood [12]. Protection presumably starts at very early stage, when embryos are exposed to the farming environment via the pregnant mother [11,13-16]. However, many confounding factors, such as the health status of the mother, placental transfer of certain metabolites and 
whether or not the baby receives breast feeding, influence the newborn's risk to develop allergies this will not be discussed in this short review. Finally, children who grow up on farms are regularly nourished with unprocessed cow's milk, and this appeared to be a very important contributor to the protective effect $[11,17,18]$. The reduced risk of atopy in non-farmer's children living in close proximity to a farm could be explained by drinking raw cow's milk [19]. A whole body of evidence unveiled several active components in raw cow's milk and this is discussed in a recent review [20].

\section{Farm-related exposures that confer protection against allergy}

Several farm-related factors that are inversely associated with the risk to develop atopy, such as livestock and cowshed (straw, hay, manure), presumably instigate an altered environmental microbiome. Indeed, living on a farm is associated with an increased variety of environmental organisms, and this increased biodiversity protects against asthma [21]. Likewise, a recent study showed that a stronger protection was found in farms that clusters with other farms and therefore harbor a broader microbial diversity [19]. Amish home dust contained higher endotoxin levels and Proteobacteria and effectively suppressed asthma features in mice, compared to Hutterite home dust [10]. However, dust from Amish and Hutterite farms were both able to suppress asthma features in mice [22]. This, together with the fact that Hutterite children do not spend time around the farm before the age of 6 , indicates that close contact to biodiversity and timing are crucial for protection. Because microbial diversity can be transferred from outside towards indoor [23], it will likely affect the host exposure to metabolites as well as the host microbiome itself (Figure 1).

\section{Exposure to Microbial Metabolites and Plant Metabolites}

Several metabolites have been studied in the context of allergic diseases and were shown to be either protective or rather a risk factor. The most commonly studied microbial agent is endotoxin or lipopolysaccharide (LPS), derived from Gram-negative bacteria. Multiple studies report an inverse relationship between endotoxin content in farmer's mattress- or home dust with the risk to develop hay fever, asthma or atopic sensitization [10,24-28]. Nevertheless, there was no or even a positive association between endotoxin in home dust and non-atopic or virus-triggered wheeze [24,29]. Additionally, increased endotoxin levels in home dust reduced lung function amongst asthmatics [30,31] and exacerbated exercise-induced asthma [26]. Similar contradictory findings were reported for $\beta$-glucan, a bacterial and fungal contaminant that causes a more severe, steroid-resistant asthmatic response to allergens in vivo [32-34]. While some reports found no association between $\beta$-glucan in home dust and the risk for atopy $[28,35]$, others claim it is inversely correlated to moderate to severe asthma in adults [31]. Likewise, certain fungal species and extracellular polysaccharide from Penicillum and Aspergillus species in farmer's homes have been associated with a reduced risk for asthma [28,36,37]. Presumably, the dosing and timing of exposure to bacterial or fungal contaminants defines whether or not they counteract or exacerbate allergic diseases.

A farm environment is also enriched in non-microbial and/or plant-derived metabolites, which can also affect the risk for atopy. As such, farmer's children have elevated 
antibodies against $\mathrm{N}$-glycolylneuraminic acid, derived from livestock, and this is inversely correlated with wheeze and asthma in non-atopic children [38]. Cowshedderived N-glycolylneuraminic acid and grass arabinogalactan protect against allergic airway inflammation in mice [38,39].

\section{Host Microbiome}

Besides releasing metabolites, environmental microbes can also colonize and change the host microbiome at various barrier sites. Two recent studies showed that living on a farm causes increased microbial diversity in mattress dust, nose and throat $[40,41]$. Lower diversity in the nose, but not in the throat, was correlated with asthma. Additionally, the presence of Moraxella species in the nose and lower airways enhanced the risk for asthma but this was not the case in farmer's children [41,42]. Experimental evidence shows that intranasal administration of cowshed-derived bacterial strains, such as Lactococcus lactis, Acinetobacter lwoffii or Staphylococcus sciuri can protect from airway inflammation in mice $[43,44]$.

Even though the nasal microbiome appeared to be important for protection, the association between mattress dust microbial diversity and asthma in farmer's children was more pronounced [40]. This indicates an involvement beyond the upper airways microbiome diversity. There is a well-established gut-lung axis and the important role of gut microbiome in the etiology of asthma has been reported before [45]. Until now, no study addressed how the gut microbiome in farmer's population could be involved in the protection from atopy. Nevertheless, oral exposure of mice to dust from homes with pets results in Lactobacillus johnsonii abundance in the gut and protects from allergic airway inflammation [46].

The skin is the largest barrier site and is also colonized by a microbiome which has been shown to have a major impact on immune regulation $[47,48]$. Hanski and colleagues showed that environmental biodiversity is reflected in skin microbial diversity and this was lower in atopic individuals [49]. Noteworthy, only the Acinetobacter genus was negatively associated with the risk for atopy [49]. Acinetobacter lwoffii colonization of the skin was later shown to suppress murine allergic airway inflammation induced by epicutaneous sensitization to OVA [50]. Notably, a recent clinical trial observed that the use of Bacillus-impregnated bedding covers suppressed symptoms in patients with HDM-allergic rhinitis, despite similar allergen levels in mattress dust [51]. This might be a useful tool to validate how farm-related microbial exposures could protect against allergies in clinical trials.

\section{Immunology and potential underlying mechanisms}

Microbial communities at barrier sites instruct and skew the immune system from very early stage onwards. Chronic parasitic infections, which are like allergies mediated by Th2-cells, are regulated by regulatory T-cells (Tregs) [52]. Therefore, unraveling the mechanistic insights of the biodiversity hypothesis has been focusing on the loss Tregs to suppress allergic Th2 responses [53]. Children from farm-exposed mothers were shown to have increased numbers of Tregs until the age of 4,5 but this switched at the 
age of 6, indicating a crucial time window for Treg-mediated asthma protection [54-56]. Microbial colonization of murine neonatal lungs is required for generation of Tregs, which in turn reduce susceptibility to allergic sensitization in neonates [57]. Likewise, introducing bacterial metabolites (e.g. butyrate and Polysaccharide A) or non-microbial metabolites (e.g. N-glycolylneuraminic acid) in murine gut or nose induces Tregs that can counteract allergic airway responses [38,58-60].

Colonization of bacterial communities at barrier sites is also known to induce type 17 immune responses and one report showed that exposure to farm dust extract provoked such responses in agricultural workers and in mice [61]. Even though this could cause increased asthma severity [34], type 17 T-cells are also able to regulate type 2 immunity [62]. Likewise, microbiota-induced type 17 responses in the skin enhance innate barrier immunity and might thus also reduce susceptibility for atopic sensitization via the skin $[47,48]$.

Sensitization to allergens is known to be initiated by an intimate crosstalk between barrier epithelial cells and dendritic cells (DCs) [63]. Farm children had less circulating DCs, particularly the type 2 conventional DCs (cDC2s) that were previously shown to be responsible for sensitization $[64,65]$. Cultured DCs that were stimulated with cowshed dust, expressed higher levels of co-stimulatory molecules CD86 and CD80, mainly produced IL-10 and were unable to sensitize mice to allergens [66,67]. Recent work showed that inhaled Acinetobacter lwoffii could protect neonatal mice from airway hyperresponsiveness by preventing HDM-induced expansion of cDC2s and monocytederived DCs in the lungs [68]. This reduction in DC numbers directly impacted IL$13^{+} \mathrm{CD} 4^{+} \mathrm{T}$-cells, which were responsible for the increased susceptibility of neonates for allergic airway hyperresponsiveness [68]. This partially explains how a farming environment could particularly protect children at young age.

Additionally, there is growing evidence that innate immune responses play a major role in the protective effect of a farming environment. Farming was repeatedly reported with increased expressions of Toll-like receptors (TLR) or TLR-signaling molecules on circulating leukocytes [69,70] and SNPs in TLRs and/or CD14 have been associated with farming $[71,72]$. TNF and IRF7, two key proteins in the innate response to microbes, appeared to be important network hubs from all the differentially expressed genes between Amish and Hutterite circulating leukocytes, most of which showed higher expression in Amish versus Hutterite children [10]. This suggests a reinforced innate immunity in Amish children, which could possibly confer protection to allergens. Interestingly, a recent study designated TNF as a key to regulate endotoxin-mediated protection from asthma [73]. Simultaneous exposure to LPS and HDM induces TNF, which in turn upregulates T-bet expression in CDC2s that then skew immune responses towards Th1 [73]. Our previous work showed that endotoxin-mediated protection, occurred at the level of the bronchial epithelial cells [74]. Repeated intranasal exposures to endotoxin or farm dust, prior to HDM, induced the expression of TNFAIP3 (coding for A20, a negative regulator of $\mathrm{NFKB}$ signaling) in bronchial epithelial cells, resulting in an increased activation threshold for allergens like HDM. Endotoxin-exposed epithelial cells did not produce Th2-skewing cytokines (GM-CSF, CCL20 and IL-33) upon HDM 
stimulation and therefore failed to instruct DCs to mount an allergen-specific Th2 response [74]. Intriguingly, a SNP in TNFAIP3 locus was associated with protection from allergy but only in farm children [74] and TNFAIP3 expression was also increased in peripheral blood cells of the Amish children compared to the Hutterite children [10]. Another clear genetic-environment interaction is SNP in the 17q21 locus, which encodes the genes ORMDL3 and GSDMB. In fact, the risk for asthma caused by the $17 \mathrm{q} 21$ genotype is confined to children with virus-triggered wheeze in early life, whereas this genotype rather confers protection in farmer's children [75].

\section{Conclusion}

Despite the growing body of evidence showing that some particular farming environments are protective against allergy development, there are still many unanswered questions. It would be important to identify the "protective" factors contained in farm dust. Also, more murine and translational studies are required to identify the cell populations at the basis of protection from allergy, to be able to more precisely study the mechanisms underlying the protective effect of certain types of farms.

\section{References}

1. Bach J-F: The effect of infections on susceptibility to autoimmune and allergic diseases. $N$. Engl. J. Med. 2002, 347:911-920.

2. Platts-Mills TAE: The allergy epidemics: 1870-2010. J. Allergy Clin. Immunol. 2015, 136:3-13.

3. Pols DHJ, Wartna JB, van Alphen EI, Moed H, Rasenberg N, Bindels PJE, Bohnen AM: Interrelationships between Atopic Disorders in Children: A MetaAnalysis Based on ISAAC Questionnaires. PLOS ONE 2015, 10:e0131869.

4. Flandroy L, Poutahidis T, Berg G, Clarke G, Dao M-C, Decaestecker E, Furman E, Haahtela $\mathrm{T}$, Massart $\mathrm{S}$, Plovier $\mathrm{H}$, et al.: The impact of human activities and lifestyles on the interlinked microbiota and health of humans and of ecosystems. Sci. Total Environ. 2018, 627:1018-1038.

5. Schröder PC, Li J, Wong GWK, Schaub B: The rural-urban enigma of allergy: what can we learn from studies around the world? Pediatr Allergy Immunol 2015, 26:95-102.

6. Illi S, Depner M, Genuneit J, Horak E, Loss G, Strunz-Lehner C, Büchele G, Boznanski A, Danielewicz H, Cullinan P, et al.: Protection from childhood asthma and allergy in Alpine farm environments-the GABRIEL Advanced Studies. J. Allergy Clin. Immunol. 2012, 129:1470-7.e6.

7. Riedler J, Eder W, Oberfeld G, Schreuer M: Austrian children living on a farm have less hay fever, asthma and allergic sensitization. Clin Exp Allergy 2000, 30:194-200.

8. Ehrenstein Von OS, Mutius von E, Illi S, Baumann L, Böhm O, Kries von R: 
Reduced risk of hay fever and asthma among children of farmers. Clin Exp Allergy 2000, 30:187-193.

9. Borlée F, Yzermans CJ, Krop EJM, Maassen CBM, Schellevis FG, Heederik DJJ, Smit LAM: Residential proximity to livestock farms is associated with a lower prevalence of atopy. Occup Environ Med 2018, 75:453-460.

10. Stein MM, Hrusch CL, Gozdz J, Igartua C, Pivniouk V, Murray SE, Ledford JG, Marques Dos Santos M, Anderson RL, Metwali N, et al.: Innate Immunity and Asthma Risk in Amish and Hutterite Farm Children. N. Engl. J. Med. 2016, 375:411-421.

11. Riedler J, Braun-Fahrländer C, Eder W, Schreuer M, Waser M, Maisch S, Carr D, Schierl R, Nowak D, Mutius von E, et al.: Exposure to farming in early life and development of asthma and allergy: a cross-sectional survey. Lancet 2001, 358:1129-1133.

12. Douwes J, Travier N, Huang K, Cheng S, McKenzie J, Le Gros G, Mutius von E, Pearce $\mathrm{N}$ : Lifelong farm exposure may strongly reduce the risk of asthma in adults. Allergy 2007, 62:1158-1165.

13. Douwes J, Cheng S, Travier N, Cohet C, Niesink A, McKenzie J, Cunningham C, Le Gros G, Mutius von E, Pearce N: Farm exposure in utero may protect against asthma, hay fever and eczema. European Respiratory Journal 2008, 32:603-611.

14. House JS, Wyss AB, Hoppin JA, Richards M, Long S, Umbach DM, Henneberger PK, Beane Freeman LE, Sandler DP, Long O'Connell E, et al.: Early-life farm exposures and adult asthma and atopy in the Agricultural Lung Health Study. J. Allergy Clin. Immunol. 2017, 140:249-256.e14.

15. Ege MJ, Bieli C, Frei R, van Strien RT, Riedler J, Ublagger E, Schram-Bijkerk D, Brunekreef $B$, van Hage $M$, Scheynius A, et al.: Prenatal farm exposure is related to the expression of receptors of the innate immunity and to atopic sensitization in school-age children. Journal of Allergy and Clinical Immunology 2006, 117:817-823.

16. Pfefferle PI, Büchele G, Blümer N, Roponen M, Ege MJ, Krauss-Etschmann S, Genuneit J, Hyvärinen A, Hirvonen M-R, Lauener R, et al.: Cord blood cytokines are modulated by maternal farming activities and consumption of farm dairy products during pregnancy: the PASTURE Study. J. Allergy Clin. Immunol. 2010, 125:108-15.e1-3.

17. Waser M, Michels KB, Bieli C, Flöistrup H, Pershagen G, Mutius von E, Ege M, Riedler J, Schram-Bijkerk D, Brunekreef B, et al.: Inverse association of farm milk consumption with asthma and allergy in rural and suburban populations across Europe. Clin Exp Allergy 2007, 37:661-670.

18. Loss G, Apprich S, Waser M, Kneifel W, Genuneit J, Büchele G, Weber J, Sozanska B, Danielewicz $\mathrm{H}$, Horak $\mathrm{E}$, et al.: The protective effect of farm milk consumption on childhood asthma and atopy: the GABRIELA study. J. Allergy Clin. Immunol. 2011, 128:766-773.e4. 
19. Müller-Rompa SEK, Markevych I, Hose AJ, Loss G, Wouters IM, Genuneit J, BraunFahrländer C, Horak E, Boznanski A, Heederik D, et al.: An approach to the asthma-protective farm effect by geocoding: Good farms and better farms. Pediatr Allergy Immunol 2018, 29:275-282.

20. Abbring S, Hols G, Garssen J, van Esch BCAM: Raw cow's milk consumption and allergic diseases - The potential role of bioactive whey proteins. European Journal of Pharmacology 2019, 843:55-65.

21. Ege MJ, Mayer M, Normand A-C, Genuneit J, Cookson WOCM, Braun-Fahrländer C, Heederik D, Piarroux R, Mutius von E, GABRIELA Transregio 22 Study Group:

Exposure to environmental microorganisms and childhood asthma. N. Engl. J. Med. 2011, 364:701-709.

22. Gozdz J, Ober C, Vercelli D: Innate Immunity and Asthma Risk. N. Engl. J. Med. 2016, 375:1898-1899.

23. Lee MK, Carnes MU, Butz N, Azcarate-Peril MA, Richards M, Umbach DM, Thorne PS, Beane Freeman LE, Peddada SD, London SJ: Exposures Related to House Dust Microbiota in a U.S. Farming Population. Environ. Health Perspect. 2018, 126:067001.

24. Braun-Fahrländer C, Riedler J, Herz U, Eder W, Waser M, Grize L, Maisch S, Carr D, Gerlach F, Bufe A, et al.: Environmental exposure to endotoxin and its relation to asthma in school-age children. N. Engl. J. Med. 2002, 347:869-877.

25. Karvonen AM, Hyvärinen A, Gehring U, Korppi M, Doekes G, Riedler J, BraunFahrländer C, Bitter S, Schmid S, Keski-Nisula L, et al.: Exposure to microbial agents in house dust and wheezing, atopic dermatitis and atopic sensitization in early childhood: a birth cohort study in rural areas. Clin Exp Allergy 2012, 42:1246-1256.

26. Oluwole O, Rennie DC, Senthilselvan A, Dyck R, Afanasieva A, Kirychuk S, Katselis $G$, Lawson JA: The association between endotoxin in house dust with atopy and exercise-induced bronchospasm in children with asthma. Environ. Res. 2018, 164:302-309.

27. Mendy A, Gasana J, Vieira ER, Forno E, Patel J, Kadam P, Ramirez G: Endotoxin exposure and childhood wheeze and asthma: a meta-analysis of observational studies. J Asthma 2011, 48:685-693.

28. Douwes J, van Strien R, Doekes G, Smit J, Kerkhof M, Gerritsen J, Postma D, de Jongste J, Travier N, Brunekreef B: Does early indoor microbial exposure reduce the risk of asthma? The Prevention and Incidence of Asthma and Mite Allergy birth cohort study. Journal of Allergy and Clinical Immunology 2006, 117:1067-1073.

29. Thorne PS, Mendy A, Metwali N, Salo P, Co C, Jaramillo R, Rose KM, Zeldin DC: Endotoxin Exposure: Predictors and Prevalence of Associated Asthma Outcomes in the United States. Am J Respir Crit Care Med 2015, 192:1287-1297. 
30. Carnes MU, Hoppin JA, Metwali N, Wyss AB, Hankinson JL, O'Connell EL, Richards M, Long S, Freeman LEB, Sandler DP, et al.: House Dust Endotoxin Levels Are Associated with Adult Asthma in a U.S. Farming Population. Ann Am Thorac Soc 2017, 14:324-331.

31. Oluwole O, Rennie DC, Senthilselvan A, Dyck R, Afanasieva A, Kirychuk S, Katselis $G$, Lawson JA: The association between endotoxin and beta- $(1 \rightarrow 3)$-D-glucan in house dust with asthma severity among schoolchildren. Respir Med 2018, 138:38-46.

32. Hadebe S, Kirstein F, Fierens K, Chen K, Drummond RA, Vautier S, Sajaniemi S, Murray G, Williams DL, Redelinghuys $\mathrm{P}$, et al.: Microbial Ligand Costimulation Drives Neutrophilic Steroid-Refractory Asthma. PLOS ONE 2015, 10:e0134219.

33. Hadebe S, Kirstein F, Fierens K, Redelinghuys P, Murray GI, Williams DL, Lambrecht BN, Brombacher F, Brown GD: $\boldsymbol{\beta}$-Glucan exacerbates allergic airway responses to house dust mite allergen. Respiratory Research 2016, 17:35.

34. Zhang Z, Biagini Myers JM, Brandt EB, Ryan PH, Lindsey M, Mintz-Cole RA, Reponen T, Vesper SJ, Forde F, Ruff B, et al.: $\boldsymbol{\beta}$-Glucan exacerbates allergic asthma independent of fungal sensitization and promotes steroid-resistant TH2/TH17 responses. J. Allergy Clin. Immunol. 2017, 139:54-65.e8.

35. Schram-Bijkerk D, Doekes G, Douwes J, Boeve M, Riedler J, Ublagger E, Mutius von E, Benz MR, Pershagen G, van Hage M, et al.: Bacterial and fungal agents in house dust and wheeze in children: the PARSIFAL study. Clin Exp Allergy 2005, 35:1272-1278.

36. Mueller-Rompa S, Janke T, Schwaiger K, Mayer M, Bauer J, Genuneit J, BraunFahrlaender C, Horak E, Boznanski A, Mutius von E, et al.: Identification of fungal candidates for asthma protection in a large population-based study. Pediatr Allergy Immunol 2017, 28:72-78.

37. Ege MJ, Frei R, Bieli C, Schram-Bijkerk D, Waser M, Benz MR, Weiss G, Nyberg F, van Hage $M$, Pershagen $G$, et al.: Not all farming environments protect against the development of asthma and wheeze in children. J. Allergy Clin. Immunol. 2007, 119:1140-1147.

38. Frei R, Ferstl R, Roduit C, Ziegler M, Schiavi E, Barcik W, Rodriguez-Perez N, Wirz OF, Wawrzyniak M, Pugin B, et al.: Exposure to nonmicrobial Nglycolylneuraminic acid protects farmers' children against airway inflammation and colitis. J. Allergy Clin. Immunol. 2018, 141:382-390.e7.

39. Peters M, Kauth M, Scherner O, Gehlhar K, Steffen I, Wentker P, Mutius von E, Holst 0 , Bufe A: Arabinogalactan isolated from cowshed dust extract protects mice from allergic airway inflammation and sensitization. J. Allergy Clin. Immunol. 2010, 126:648-56.e1-4.

40. Birzele LT, Depner M, Ege MJ, Engel M, Kublik S, Bernau C, Loss GJ, Genuneit J, Horak E, Schloter M, et al.: Environmental and mucosal microbiota and their role in childhood asthma. Allergy 2017, 72:109-119. 
41. Depner M, Ege MJ, Cox MJ, Dwyer S, Walker AW, Birzele LT, Genuneit J, Horak E, Braun-Fahrländer C, Danielewicz H, et al.: Bacterial microbiota of the upper respiratory tract and childhood asthma. J. Allergy Clin. Immunol. 2017, 139:826-834.e13.

42. Robinson PFM, Pattaroni C, Cook J, Gregory L, Alonso AM, Fleming LJ, Lloyd CM, Bush A, Marsland BJ, Saglani S: Lower airway microbiota associates with inflammatory phenotype in severe preschool wheeze. J. Allergy Clin. Immunol. 2018, doi:10.1016/j.jaci.2018.12.985.

43. Debarry J, Garn H, Hanuszkiewicz A, Dickgreber N, Blümer N, Mutius von E, Bufe A, Gatermann S, Renz H, Holst O, et al.: Acinetobacter lwoffii and Lactococcus lactis strains isolated from farm cowsheds possess strong allergy-protective properties. Journal of Allergy and Clinical Immunology 2007, 119:1514-1521.

44. Hagner S, Harb H, Zhao M, Stein K, Holst O, Ege MJ, Mayer M, Matthes J, Bauer J, Mutius von E, et al.: Farm-derived Gram-positive bacterium Staphylococcus sciuri W620 prevents asthma phenotype in HDM- and OVA-exposed mice. Allergy 2013, 68:322-329.

45. Marsland BJ, Trompette A, Gollwitzer ES: The Gut-Lung Axis in Respiratory Disease. Ann Am Thorac Soc 2015, 12 Suppl 2:S150-6.

46. Fujimura KE, Demoor T, Rauch M, Faruqi AA, Jang S, Johnson CC, Boushey HA, Zoratti E, Ownby D, Lukacs NW, et al.: House dust exposure mediates gut microbiome Lactobacillus enrichment and airway immune defense against allergens and virus infection. Proc. Natl. Acad. Sci. U.S.A. 2014, 111:805-810.

47. Naik S, Bouladoux N, Linehan JL, Han S-J, Harrison OJ, Wilhelm C, Conlan S, Himmelfarb S, Byrd AL, Deming C, et al.: Commensal-dendritic-cell interaction specifies a unique protective skin immune signature. Nature 2015, 520:104108.

48. Harrison OJ, Linehan JL, Shih H-Y, Bouladoux N, Han S-J, Smelkinson M, Sen SK, Byrd AL, Enamorado M, Yao C, et al.: Commensal-specific T cell plasticity promotes rapid tissue adaptation to injury. Science 2018, 18:eaat6280-18.

49. Hanski I, Hertzen von L, Fyhrquist N, Koskinen K, Torppa K, Laatikainen T, Karisola P, Auvinen P, Paulin L, Mäkelä MJ, et al.: Environmental biodiversity, human microbiota, and allergy are interrelated. Proc. Natl. Acad. Sci. U.S.A. 2012, 109:8334-8339.

50. Fyhrquist N, Ruokolainen L, Suomalainen A, Lehtimäki S, Veckman V, Vendelin J, Karisola P, Lehto M, Savinko T, Jarva H, et al.: Acinetobacter species in the skin microbiota protect against allergic sensitization and inflammation. J. Allergy Clin. Immunol. 2014, 134:1301-1309.e11.

51. Berings M, Jult A, Vermeulen H, De Ruyck N, Derycke L, Ucar H, Ghekiere P, Temmerman R, Ellis J, Bachert $C$, et al.: Probiotics-impregnated bedding covers for house dust mite allergic rhinitis: A pilot randomized clinical trial. Clin Exp Allergy 2017, 47:1092-1096. 
52. Wilson MS, Taylor MD, Balic A, Finney CAM, Lamb JR, Maizels RM: Suppression of allergic airway inflammation by helminth-induced regulatory $\mathrm{T}$ cells. J. Exp. Med. 2005, 202:1199-1212.

53. Ohnmacht $\mathrm{C}$ : Microbiota, regulatory $\mathrm{T}$ cell subsets, and allergic disorders. Allergo J Int 2016, 25:114-123.

54. Schaub B, Liu J, Höppler S, Schleich I, Huehn J, Olek S, Wieczorek G, Illi S, Mutius von E: Maternal farm exposure modulates neonatal immune mechanisms through regulatory T cells. J. Allergy Clin. Immunol. 2009, 123:774-82.e5.

55. Schröder PC, Illi S, Casaca VI, Lluis A, Böck A, Roduit C, Depner M, Frei R, Genuneit J, Pfefferle PI, et al.: A switch in regulatory T cells through farm exposure during immune maturation in childhood. Allergy 2016, 72:604-615.

56. Kääriö H, Huttunen K, Karvonen AM, Schaub B, Mutius von E, Pekkanen J, Hirvonen MR, Roponen M: Exposure to a farm environment is associated with T helper 1 and regulatory cytokines at age 4.5 years. Clin Exp Allergy 2016, 46:71-77.

57. Gollwitzer ES, Saglani S, Trompette A, Yadava K, Sherburn R, McCoy KD, Nicod LP, Lloyd CM, Marsland BJ: Lung microbiota promotes tolerance to allergens in neonates via PD-L1. Nat. Med. 2014, 20:642-647.

58. Navarro S, Cossalter G, Chiavaroli C, Kanda A, Fleury S, Lazzari A, Cazareth J, Sparwasser T, Dombrowicz D, Glaichenhaus N, et al.: The oral administration of bacterial extracts prevents asthma via the recruitment of regulatory $T$ cells to the airways. Mucosal Immunol 2011, 4:53-65.

59. Roduit C, Frei R, Ferstl R, Loeliger S, Westermann P, Rhyner C, Schiavi E, Barcik W, Rodriguez-Perez N, Wawrzyniak $M$, et al.: High levels of butyrate and propionate in early life are associated with protection against atopy. Allergy 2018, doi:10.1111/all.13660.

60. Johnson JL, Jones MB, Cobb BA: Polysaccharide-experienced effector T cells induce IL-10 in FoxP3+ regulatory $\mathrm{T}$ cells to prevent pulmonary inflammation. Glycobiology 2018, 28:50-58.

61. Robbe P, Spierenburg EAJ, Draijer C, Brandsma CA, Telenga E, van Oosterhout AJM, van den Berge M, Luinge M, Melgert BN, Heederik D, et al.: Shifted T-cell polarisation after agricultural dust exposure in mice and men. Thorax 2014, 69:630-637.

62. Ohnmacht C, Park J-H, Cording S, Wing JB, Atarashi K, Obata Y, Gaboriau-Routhiau V, Marques R, Dulauroy S, Fedoseeva M, et al.: MUCOSAL IMMUNOLOGY. The microbiota regulates type 2 immunity through ROR $\gamma^{+}{ }^{+} \mathbf{T}$ cells. Science 2015, 349:989-993.

63. Deckers J, De Bosscher K, Lambrecht BN, Hammad H: Interplay between barrier epithelial cells and dendritic cells in allergic sensitization through the lung and the skin. Immunol. Rev. 2017, 278:131-144. 
64. Kääriö H, Nieminen JK, Karvonen AM, Huttunen K, Schröder PC, Vaarala O, Mutius von E, Pfefferle PI, Schaub B, Pekkanen J, et al.: Circulating Dendritic Cells, Farm Exposure and Asthma at Early Age. Scand. J. Immunol. 2016, 83:18-25.

65. Martikainen MV, Kääriö H, Karvonen A, Schröder PC, Renz H, Kaulek V, Dalphin JC, Mutius von E, Schaub B, Pekkanen J, et al.: Farm exposures are associated with lower percentage of circulating myeloid dendritic cell subtype 2 at age 6 . Allergy 2015, 70:1278-1287.

66. Gorelik L, Kauth M, Gehlhar K, Bufe A, Holst O, Peters M: Modulation of dendritic cell function by cowshed dust extract. Innate Immun 2008, 14:345-355.

67. Martikainen M-V, Rönkkö TJ, Schaub B, Täubel M, Gu C, Wong GW, Li J, Pekkanen J, Komppula $\mathrm{M}$, Hirvonen $\mathrm{M}-\mathrm{R}$, et al.: Integrating farm and air pollution studies in search for immunoregulatory mechanisms operating in protective and highrisk environments. Pediatr Allergy Immunol 2018, doi:10.1111/pai.12975.

68. Saglani S, Gregory LG, Manghera AK, Branchett WJ, Uwadiae F, Entwistle LJ, Oliver RA, Vasiliou JE, Sherburn R, Lui S, et al.: Inception of early-life allergen-induced airway hyperresponsiveness is reliant on $\mathrm{IL-13+CD4+T}$ cells. Science Immunology 2018, 3:eaan4128.

69. Loss G, Bitter S, Wohlgensinger J, Frei R, Roduit C, Genuneit J, Pekkanen J, Roponen M, Hirvonen M-R, Dalphin J-C, et al.: Prenatal and early-life exposures alter expression of innate immunity genes: the PASTURE cohort study. J. Allergy Clin. Immunol. 2012, 130:523-30.e9.

70. Frei R, Roduit C, Bieli C, Loeliger S, Waser M, Scheynius A, van Hage M, Pershagen G, Doekes G, Riedler J, et al.: Expression of genes related to anti-inflammatory pathways are modified among farmers' children. PLOS ONE 2014, 9:e91097.

71. Lau MYZ, Dharmage SC, Burgess JA, Lowe AJ, Lodge CJ, Campbell B, Matheson MC: CD14 polymorphisms, microbial exposure and allergic diseases: a systematic review of gene-environment interactions. Allergy 2014, 69:14401453.

72. Lau MYZ, Dharmage SC, Burgess JA, Win AK, Lowe AJ, Lodge C, Perret J, Hui J, Thomas PS, Morrison S, et al.: The interaction between farming/rural environment and TLR2, TLR4, TLR6 and CD14 genetic polymorphisms in relation to early- and late-onset asthma. Sci. Rep. 2017, 7:43681.

73. Bachus H, Kaur K, Papillion AM, Marquez-Lago TT, Yu Z, Ballesteros-Tato A, Matalon S, León B: Impaired Tumor-Necrosis-Factor- $\alpha$-driven Dendritic Cell Activation Limits Lipopolysaccharide-Induced Protection from Allergic Inflammation in Infants. Immunity 2019, 50:225-240.e4.

74. Schuijs MJ, Willart MA, Vergote K, Gras D, Deswarte K, Ege MJ, Madeira FB, Beyaert R, van Loo G, Bracher F, et al.: Farm dust and endotoxin protect against allergy through A20 induction in lung epithelial cells. Science 2015, 349:1106-1110.

75. Loss GJ, Depner M, Hose AJ, Genuneit J, Karvonen AM, Hyvärinen A, Roduit C, 
Kabesch M, Lauener R, Pfefferle PI, et al.: The Early Development of Wheeze. Environmental Determinants and Genetic Susceptibility at 17q21. Am J Respir Crit Care Med 2016, 193:889-897.

\section{Acknowledgements}

This work is supported by the Flanders Research Foundation (grant number FWO13/ASP/138 to EH), an ERC advanced grant (AsthmaCrystalClear) to BNL, several FWO project grants to BNL, HH and JD, and a Ghent University grant (GOA 01G02817). 


\section{Figure legend}

Figure 1: Early exposure to a farming environment protects from the development of allergy. This type of environment is rich in microbes that can produce metabolites and colonize the host, leading to a microbiome change. This will in turn impact on immune cells and barrier epithelial cells, and modify the way they respond to allergens. 
Farm-related factors

early exposure

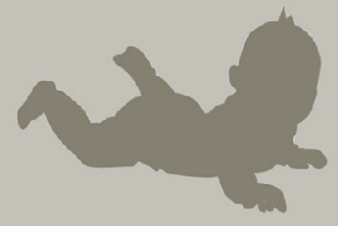

Consumption raw cow's milk

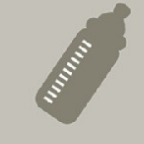

Proximity to livestock

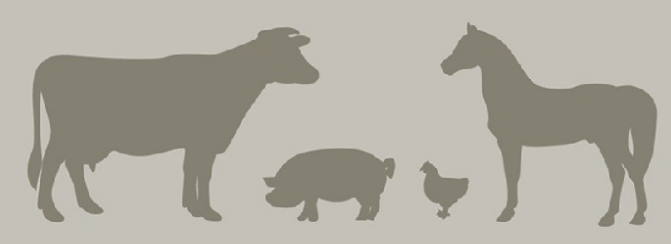

Exposure to

straw, hay, manure
Farm-related exposures

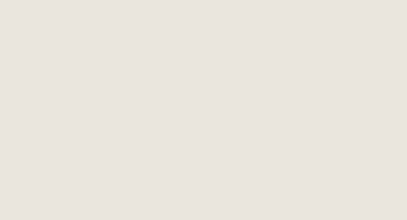

$-9-$ Acinetobacter Iwoffii

Iactococcus lactis

\&. Staphylococcus sciut

गT Lactobacillus johnsoni

Host

Microbiome
Host immune response

ex vivo DC

(regulatory- JW/ $\longrightarrow$ TCD86 and CD80

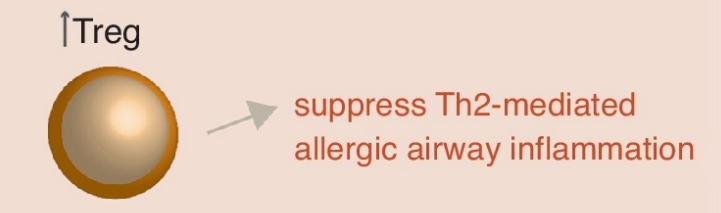

\section{IRORgt' T-cell}

$\longrightarrow$ regulate Th2-mediated immunity

Environmenta Microbiome

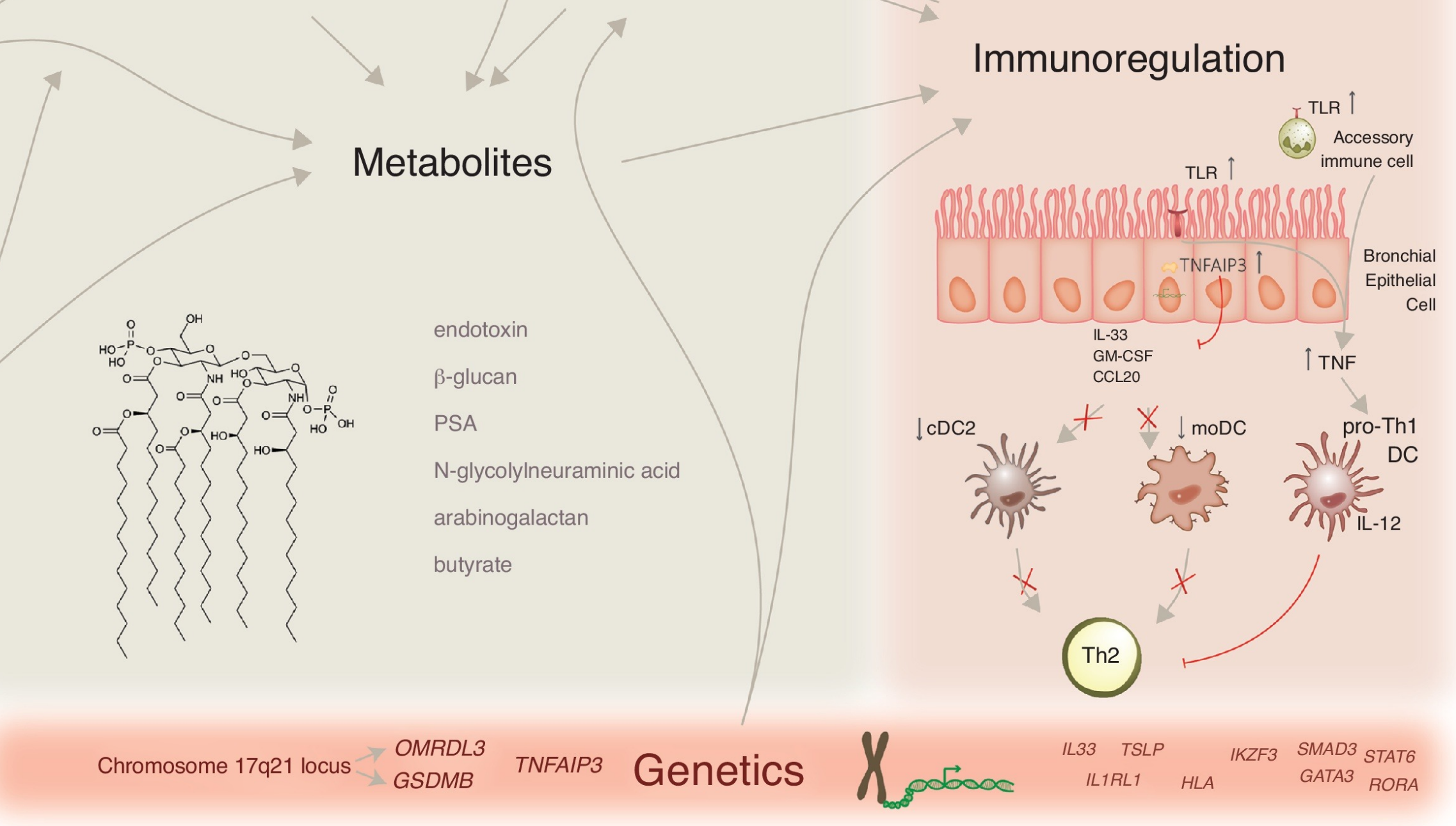


Table 1: Selection of recent evidence for farm-related exposures that affect allergy or asthma

\begin{tabular}{|c|c|c|c|c|c|}
\hline \multicolumn{2}{|c|}{ Nature of exposure } & $\begin{array}{l}\text { Area of } \\
\text { exposure }\end{array}$ & $\begin{array}{l}\text { Effect on allergy } \\
\text { of asthma }\end{array}$ & Subject of study & Reference \\
\hline \multirow{11}{*}{$\begin{array}{l}\text { Microbial } \\
\text { and noe. } \\
\text { microbsal } \\
\text { agents }\end{array}$} & \multirow{4}{*}{ Endotasin } & $\begin{array}{l}\text { Mattress, } \\
\text { Home dust }\end{array}$ & \multirow{2}{*}{$\leftrightarrow$} & Sabjects living on a farm or in rural arta & $20,25-29$ \\
\hline & & Murise airways & & Experimental mouse model for asthma & 76,77 \\
\hline & & Home dust & $\begin{array}{l}\text { No relation of } \\
\text { exacertation }\end{array}$ & $\begin{array}{l}\text { Patients with non-abopic (eq. exercise-tnduced) of } \\
\text { ninal triggered whereze }\end{array}$ & $25,27,90$ \\
\hline & & $\begin{array}{l}\text { Mattress, } \\
\text { Hame dust }\end{array}$ & $\begin{array}{l}\text { Bedoced lang } \\
\text { function }\end{array}$ & Asthmatic patients (both atopic and son-atopic) & $31-32$ \\
\hline & \multirow{3}{*}{ B-glacan } & Home dust & $\rightarrow$ & Children with asthma & 32 \\
\hline & & Hame dust & \multirow{2}{*}{ Exacerbation } & Children with asthma & 35 \\
\hline & & Murine airways & & Experimental mouse model for withma & $35-55$ \\
\hline & $\begin{array}{l}\text { Extracellular } \\
\text { polysaccharsde }\end{array}$ & Hame dust & $\leftrightarrow$ & Subjects Liwing on a farm & $29,37.35$ \\
\hline & N- & $\begin{array}{l}\text { Muribodies in } \\
\text { Serum }\end{array}$ & $\leftrightarrow$ & Non-atapic children living on a farm & 39 \\
\hline & minicacid & Murise airways & $\leftrightarrow$ & Experimental mouse model for asthma & 39 \\
\hline & Arabinogalactan & Murine airways & $\Leftrightarrow$ & Experimenal mouse model for asthma & 40 \\
\hline \multirow{8}{*}{$\begin{array}{c}\text { Bacteria } \\
\text { that } \\
\text { calonize } \\
\text { the bast }\end{array}$} & $\begin{array}{l}\text { Maraxilla } \\
\text { species }\end{array}$ & $\begin{array}{l}\text { Human upper } \\
\text { and lower }\end{array}$ & Exacerbation & $\begin{array}{l}\text { Children that dant live on farm. Farmers' children } \\
\text { are protected }\end{array}$ & 42,43 \\
\hline & $\begin{array}{l}\text { Lactococous } \\
\text { hactis }\end{array}$ & Murine airnwys & $\leftrightarrow$ & Experimeatal mouse model for asthma & 44 \\
\hline & $\begin{array}{l}\text { Sraphyblococcus } \\
\text { sciowi }\end{array}$ & Murine airways & $\leftrightarrow$ & Experimental mouse model for asthma & 45 \\
\hline & \multirow{3}{*}{$\begin{array}{l}\text { Acisenenticter } \\
\text { lavifiti }\end{array}$} & $\begin{array}{l}\text { Human skin } \\
\text { colonization }\end{array}$ & $\begin{array}{l}\text { Correlation with } \\
\text { IL-10 in PHMCs }\end{array}$ & $\begin{array}{l}\text { Healthy adolescents, living is an area with rich } \\
\text { biodiversity }\end{array}$ & 50 \\
\hline & & Murise kirwwys & \multirow{2}{*}{$\leftrightarrow$} & Experimental mouse model for asthma & 44.69 \\
\hline & & Murine skin & & $\begin{array}{l}\text { Asthma model induced by epicutaneous } \\
\text { sensitization to OVA }\end{array}$ & 51 \\
\hline & $\begin{array}{l}\text { Lactobaciürs } \\
\text { johnsoniй }\end{array}$ & Muribe gut & $\leftrightarrow$ & Experimental mouse model for asthma & 47 \\
\hline & Bacilïus species & Mattress & $\rightarrow$ & Patsens with allergoc rhinits & 52 \\
\hline
\end{tabular}

Abbreviations: - : inverse relationship, OVA-Ovalbumin, IL-10: Interleukin-10, PBMCs: Peripheral Blood Mononuclear Cells 